the oil. The corresponding large difference noted at $10.67 \mu$ results from the contribution at that wavelength of the bending vibration absorption of the carboxylic group, which is, of course, present only in the acid.

Finally, the results of the absorption spectra measurements on punicic acid in this present work are in good agreement with those previously reported for the parent oil. In view of the fact that the latter set of data has previously been assumed characteristic of the component acid, for the identification of the unsaturation, this conclusion would seem to justify the suggested cis-cis-trans configuration.

Acknowledgments are due to the President, Council and Director of the Research Association of British Paint, Colour and Varnish Manufacturers for permission to publish this communication.

N. H. E. Ahlers

A. C. Dennrson

L. A. O'NEILI

Paint Research Station, Waldegrave Road,

Teddington, Middlesex. Dec. 10.

Toyama, X., and Tsuchiya, T., J. Soc. Chem. Indust., Japan, 38, 182 (1935)

'Toyama, Y., and Hozaki, K., J. Soc. Chem. Indust., Japan, 40, 249 (1937).

'Farmer, E. H., and van den Heuvel, F. A., J. Chem. Soc., 1809 (1936).

- Ahlers, N. H. E., Brett, R. A., and McTaggart, N. G., J. App. Chem., $3,433(1953)$

- Ahlers, N. H. E., and McTaggart, N. G., J. Sci. Food Agric., 5, 75 $(1954)$.

-Ahlers, N. H. E., J. Oil Col. Chem. Assoc., 33, 421 (1950),

7 Ablers, N. H. E., and Freedman, H. P., Nature, 172, 260 (1953).

\section{Nature of the Catalyst in the Decomposition of Carbon Monoxide in Presence of Iron}

THe decomposition of carbon monoxide by the reaction, $2 \mathrm{CO}=\mathrm{CO}_{2}+\mathrm{C}$, is catalysed in presence of iron, the maximum deposit of carbon taking place at $550^{\circ} \mathrm{C}$. There is, however, no unanimity of opinion regarding the actual nature of the catalyst. Both metallic iron ${ }^{1,2}$ and iron carbide ${ }^{3,4}$ have been claimed to be the catalyst for the reaction.

The lack of catalytic activity of powders prepared from metallic iron in bringing about decomposition of carbon monoxide has been put forward as a strong point against the 'metal' theory. This argument does not seem to be tenable, since metallic iron is prepared at very high temperatures at which catalysts are known to lose their activities, probably due to the metal atoms finding their proper positions in the lattice. To obtain fuller information on this problem, the activities of the following materials in bringing about decomposition of carbon monoxide have been determined: (i) iron powder obtained at lower temperatures by reducing ferrous oxalate in hydrogen; (ii) iron carbide $(\mathrm{Fe}, 92 \cdot 3$, and $\mathrm{C}$, $7 \cdot 2$ per cent) isolated from a sample of white cast iron (C, 3.08; $\mathrm{Mn}, 0.216 ; \mathrm{Si}, 0.88 ; \mathrm{P}, 0.21$ and $\mathrm{S}, 0.10$ per cent) by anodic dissolution in 5 per cent aqueous hydrochlorio acid ${ }^{5}$; and (iii) iron powder obtained by reducing this carbide in hydrogen.

(i) Metallic iron obtained in a fine state of subdivision by reducing ferrous oxalate $(0.1 \mathrm{gm}$.$) in$ hydrogen at $350^{\circ} \mathrm{C}$. deposited $0.12 \mathrm{gm}$. carbon when carbon monoxide was passed for two hours over the reduced material heated at $550^{\circ} \mathrm{C}$.; the higher the temperature of reduction of the oxalate in hydrogen, the lower is the activity of the iron powder produced. (ii) The carbide $\left(0.2 \mathrm{gm}\right.$.) heated to $550^{\circ} \mathrm{C}$. did not precipitate any carbon when carbon monoxide was passed over it; at this temperature maximum deposition of carbon would be expected. (iii) $R_{\theta}$. duction of this carbide $(0.2 \mathrm{gm}$.) by heating it in hydrogen at $900^{\circ} \mathrm{C}$. for two hours produced iron powder which catalysed the decomposition of carbon monoxide at $550^{\circ} \mathrm{C}$., $0.103 \mathrm{gm}$. of carbon being deposited in two hours.

These results seem to show clearly that metallic iron is the active catalyst which brings about the decomposition of carbon monoxide.

We thank Dr. S. R. Sen Gupta, principal of the Bengal Engineering College, for his interest in this work.

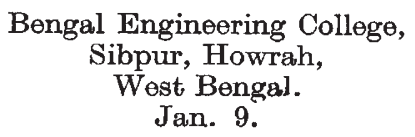

Bengal Engineering College, Sibpur, Howrah, West Bengal. Jan. 9.

1 Baukloh, W., and Speltzler, E., Arch. f. d. Eisenhüttenwis., 13, 223 (1939-40).'

Baukloh, W., Chatterjee, B., and Das, P. P., Trans. Ind. Inst. Metals, 4, 271 (1951).

${ }^{3}$ Fischer, F., and Bahr, H. A., "Gesam. Abhandl. Kenntnis der Kohle", 8, 225 (1929)

- Koerber, F., Wiemer, H., and Fischer, W. A., Arch. f. d. Eisen hüttenwis., 17, 43 (1943-44).

- Papier, J., C.R. Acad. Sci. Paris, 235, 619 (1952)

\section{The Monosubstituted Pteridines}

THE synthesis of a wide variety of monosubstituted pteridines was begun in this Department in 1949 , in order to provide less complex pteridines than occur in Nature. We are using the new material to investigate the connexion between constitution and physico-chemical properties (particularly solubility, ionization constants, stability to hydrolysis, spectra). This is intended as a contribution towards relating structure to biological action.

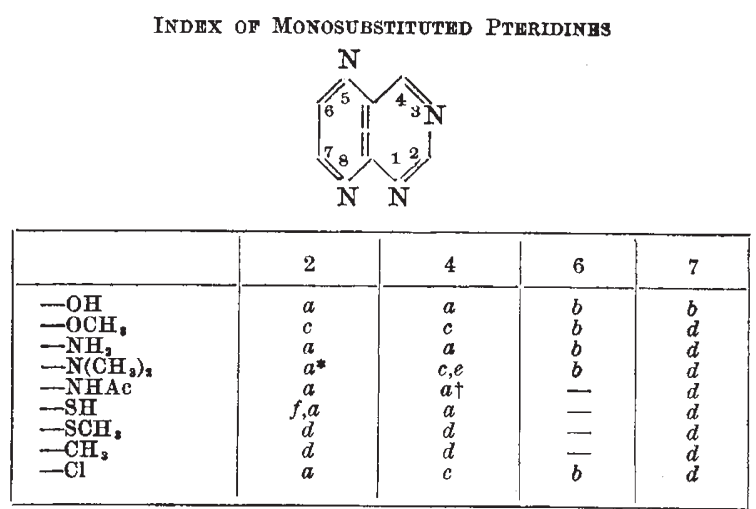

* The 2-methylamino-analogue is also known (ref. c). 4 4-Hydrazinopteridine is also known (ref. $d$ ).

a Albert, A., Brown, D. J., and Cheeseman, G., J. Chem. Soc., 474

$b$ Albert, A., Brown, D. J., and Cheeseman, G. J. Chem Soc, 1620 (1952).

c Albert, A., Brown, D. J., and Cheeseman, G., J. Chem. Soc., 4219 (1952).

d Albert, A., Brown, D. J., and Wood, II. C. S. (in prenaration).

The 4-diethylamino-analogue is also known; Boon, W. R., and

$f$ Elion, G. B., and Hitchings, G. H., J. Amer. Chem. Soc., 69, 2553 (1947). 